\title{
Potential of Vermicompost for Sustainable Crop Production and Soil Health Improvement in Different Cropping Systems
}

\author{
Anil Kumar", C.H. Bhanu Prakash, Navjot Singh Brar and Balwinder Kumar \\ Farm Science Centre, Guru Angad Dev Veterinary \& Animal Sciences University, Tarn \\ Taran, Punjab, India \\ *Corresponding author
}

\section{A B S T R A C T}

\begin{tabular}{|c|}
\hline Keywords \\
\hline $\begin{array}{l}\text { Earthworms, Plant } \\
\text { growth, Vermicompost, } \\
\text { Soil health, Soil structure }\end{array}$ \\
\hline Article Info \\
\hline $\begin{array}{l}\text { Accepted: } \\
10 \text { September } 2018 \\
\text { Available Online: } \\
10 \text { October } 2018\end{array}$ \\
\hline
\end{tabular}

Keywords

\section{Introduction}

The use of chemical fertilizers has increased tremendously from green revolution leading to heavy dependence on chemical fertilizer in conventional agricultural system. The application of chemical fertilizers, no doubt has increased the crop productivity many folds, but their continuous and imbalanced application has also produced detrimental effects on soil health due to which crop yields have become stagnated in past few decades. The long term fertilizer experimental studies indicated that continuous sole application of chemical fertilizer in imbalanced manner produce detrimental effects on soil physical, chemical and biological properties further, inducing secondary and micronutrient deficiencies in soil, nutrient imbalance in soil and plants, environmental hazards and decrease in total factor productivity. Microbial population in soil also severely affected due to imbalanced fertilizer application. Moreover, excessive fertilizer applications are also contaminating surface and underground water bodies especially by nitrate leaching (Pimentel, 1996) and causing detrimental effects on environment, which in turn is causing serious hazards to human and animal health. Therefore, in present context, there is dire need to follow climate resilient integrated crop management modules so that soil health and crop productivity could be sustained for longer time. In above scenario, one of the 
possible options to reduce the use of chemical fertilizer could be recycling of organic wastes. Thus, inclusion of vermicompost organic manure in crop production is a better alternative for improving soil health, crop productivity and quality as it exert a significant positive influence on soil properties and microbial population.

Vermicompost is the method of using earthworms to transform organic waste into nutrient rich compost. Soil earthworms play an important role in agriculture, it decomposes dead organic litter by consuming them and release as castings. The earthworms accelerate decomposition of plant litter and organic matter and improve soil fertility by releasing mineral elements in the forms that are easily uptake by plants (Curry, 1987). Vermicompost contains most nutrients in plant available form such as nitrates, phosphates, exchangeable calcium and soluble potassium (Edwards, 1998; Orozco, 1996). The behavioural activity of earthworms that is feeding, burrowing and casting, modify the physical, chemical and biological properties of organic matter and soil for plant growth and nutrient acquisition. Due to large surface area, vermicompost offers several micro sites for nutrient retention and exchange and microbial activity (Shi-wei and $\mathrm{Fu}-Z$ hen, 1991). Vermicompost is usually rich in microbial populations and diversity particularly fungi, bacteria and actinomycetes (Edwards, 1998; Tomati et al., 1987).

The compost prepared by earthworm contain several types of enzymes, hormones, vitamins, antibiotics and many essential nutrients needed for plant growth and also play important role in improving soil structure and water holding capacity, thereby improving crop productivity and quality. Vermicompost is characterized by high porosity, aeration, drainage, water holding capacity and microbial activity (Edwards and Burrows, 1988; Atiyeh et al., 1999, 2000).
As a whole, due to their different production processes, vermicompost might exhibit different physical, chemical and chemical features, which influenced plant growth and overall morphology in diverse ways. Thus, application of vermicompost as organic manure in soil built-up organic carbon, improve nutrient status, enhance cation exchange capacity, microbial activities, microbial biomass carbon and enzymatic activities.

\section{Earthworms and raw material for vermicomposting}

There are more than 3000 species of earthworms in the soil (Cook and Linden, 1996), but hardly 8-10 species are found suitable for vermicompost preparation. The best types of earthworms for vermiculture and vermicomposting are epigaeic species (litter dwellers, live in organic horizon) such as Eisenia fetida and Eudrilus eugeniae (Bansal and Kapoor, 2000; Dominguez and Edwards, 2004). These worm species like to settle on top soil and prefer to eat organic scraps such as vegetable waste, compost and organic bedding and produce richer casting than those that feed on plain soil. These worms have been recognized as the worm species that can eat as much as half of its weight on a daily basis. They work efficiently in breaking down and decaying natural remains and turning these scraps into high-quality organic compost. Further, above species of earthworms are resistant to temperature and moisture fluctuations. Moreover, these species multiply rapidly and remain active throughout the year, decompose organic material rapidly (rapid casting) and help to prepare vermicompost in shorter duration. Other species of red worms or red wigglers such as Lumbricus rubellus, Perionyx sansibaricus, Perionyx excavatus, Eisenia andreii, etc. could also be successfully used in vermicompost production (Dominguez and 
Edwards, 2004). Cattle dung or farm yard manure (FYM) is used as raw material for vermicomposting, beside that any material that can be decomposed easily such as weeds, wastes (leaves and rind) of vegetables and fruits, crop residue, roughage of the animals as well as municipal wastes of organic origin could also be utilized for vermicompost preparation (Alves and Passom, 1997; Atiyeh et al., 1999; Kamergam et al., 1999; Kiehl, 2001). The organic waste consumed by earthworms undergo physical breakdown in the gizzard, which is then exposed to various enzymes such as protease, cellulose, lipase, chitinase, amylase, etc. secreted into lumen by the gut wall and associated microbes. Above enzymes causes breakdown of complex biomolecules into simple ones. Mucus secretions of gut wall provide structural stability of vermicompost. Only $5-10 \%$ of the ingested material is absorbed by earthworms for their growth and remaining is excreted as casting.

\section{Selection of site for vermicomposting}

Generally, earthworms like to live in shady and moist places and such conditions are conducive for their faster multiplication. High temperature and dry environment are more limiting than low temperatures and water saturated environment for the worms (Rostami et al., 2009). Earthworm cannot live in standing water hence, ensure proper drainage across vermicompost unit. A temperature range between $20-30^{\circ} \mathrm{C}$ is optimum for faster multiplication and growth of the earthworms. Hence, using proper species of earthworms, excellent quality of compost can be produced in ambient temperature conditions in a short period of time. Following points should be kept in mind before making a vermicompost unit:

Select a shady and moist spot preferably under the tree or below the ventilated shed.
Ensure proper drainage across the vermicompost bed or unit and source of water should be closure to the unit.

It should be far away from biogas plant, otherwise earthworm utilise the carbon of biogas as their food and slow down the process of decomposition of material.

\section{Steps involved in vermicompost production}

Composting is an excellent option for reducing environmental threats and preparing a natural, beneficial soil additive. Actually, vermicompost is a great alternative that allows composting operation with minimal space considerations. Ease of vermicompost process and ability of its application in various scales made the vermicomposting an interesting topic almost everywhere. The production of quality vermicompost from the raw waste requires much knowledge of the process. The different steps involved in vermicompost production are elaborated below:

After selection of site for vermicompost preparation, smoothen the surface. Now, make a bed of approximately $10 \times 3 \times 3$ feet (L x B $\mathrm{x} \mathrm{H}$ ) with bricks. However, size of the bed could be decreased or increased as per the quantity of material available and need.

Moisten the surface of the bed by sprinkling the water. Now, at the base of the bed, spread 2-3 inch thick layer of dry leaves or paddy straw, etc.

Again sprinkle some amount of water over layer of dry material. Spread about 1-1.5 feet thick layer of farm yard manure or cow dung uniformly over leaves or straw layer and sprinkler water to make it sufficient moist. The cow dung should not too fresh. It should be at least 10-15 days old because fresh cow dung produce lot of heat and it can kill the earthworms. Similarly, cow dung should not 
be too old as it got decomposed and earthworms will not get any food from it.

Now, add the kitchen waste such as leaves of vegetables, fruits rind and or grasses, roughages of animals, etc. by chopping them into small pieces. Again, spread about 1-1.5 feet layer of cow dung uniformly and sprinkler sufficient quantity of water. Spread about one $\mathrm{kg}$ vermiculture (contain about $800-1000$ earthworms) over the layer of cow dung.

Again spread 2-3 inch layer of green leaves, etc. uniformly over the layer of FYM and sprinkle water. Now, cover the vermicompost bed with the help of jute/gunny bags.

For maintaining optimum moisture and temperature conditions in the vermicompost bed, regularly sprinkler the water over the gunny bags.

There should be about $35-40 \%$ moisture and $15-30^{\circ} \mathrm{C}$ temperature in the bed. Hence, regularly sprinkle water to maintain optimum conditions for earthworm growth and functioning.

If, the vermicompost unit is established in the open area then provide a shed/roof over the unit, so that shady conditions could be maintained for the unit and earthworms may be avoided from the direct contact of sun rays and rains.

By following above steps, vermicompost is ready in about 8-10 weeks' time. The vermicompost appear dark brown in colour on maturity and is very porous, granulated and free of any foul smell.

\section{Harvesting and storage of vermicompost}

When vermicompost is ready, then stop watering about one week ago and make a heap of the compost. Now, earthworm will start moving downward and gathered at the bottom of the heap. Remove the upper portion of material from heap and put it in shadow for further processing i.e. sieving and packing. It should have minimum $40 \%$ moisture and sunlight should not fall directly on heaped vermicompost, which may otherwise cause loss of moisture and nutrients from the vermicompost. Now, sieve the vermicompost and transfer the earthworms, if any to next new bed. The lower portion of vermicompost heap contain lot of earthworms, it could be used a vermiculture for preparation of vermicompost again. Now, the vermicompost is ready for use in flower pots, field, vegetable and fruit crops, etc. Vermicompost can be stored for at least one year without any loss of its quality, if the optimum moisture level $(40 \%)$ in the vermicompost is maintained.

\section{Nutritional value of vermicompost}

The nutrients content in vermicompost generally depends on the waste material or base substrate that is being used for vermicompost preparation. Similarly, earthworm species used in vermicomposting may also influence the quality of vermicompost (Chowdeppa et al., 1999). Vermicompost produced from banana wastes (leaves, pseudostem) and cattle manure in the ratio of 8: 1 on an average contained 1.5, 0.4 and $1.8 \% \mathrm{~N}, \mathrm{P}_{2} \mathrm{O}_{5}$ and $\mathrm{K}_{2} \mathrm{O}$, respectively (Ushakumari et al., 1999).

Similarly, vermicompost prepared from different organic materials such as sugarcane trash, ipomea, parthenium, neem leaves and banana peduncle is highly nutritive and increased rice productivity and improved soil fertility status (Vasanthi and Kumaraswamy, 1999). So, the nutritive value of vermicompost is highly dependent on base substrate used for its production. However, average nutrient concentration in the vermicompost is given in Table 1. 
Comparison between nutritive value of vermicompost and farmyard manure

The nutrient profile in vermicompost is generally higher than traditional compost (Boral et al., 1997) and it reduced the application of inorganic fertilizer to a significant extent (Table 2). However, nutritive value of vermicompost varies according to the type of organic waste used.

\section{Application of vermicompost in soil}

Vermicompost can be applied to any crop including field and horticultural crops. There are many reports in literature showing beneficial effects on plant and soil following vermicompost application. A simple method of applying vermicompost is adding it as a thin layer to soil around the plant and mixing with the soil. In general, vermicompost should be applied to soil during last ploughing. Amount of vermicompost application rates depend on its quality, nutritive value and crop to which it is to be applied. Apply 5-6 t ha ${ }^{-1}$ vermicompost in field crops, $10-12 \mathrm{tha}^{-1}$ for vegetables and 8-10 $\mathrm{kg}$ per fruit tree depending on age of tree, whereas in flower pot apply 100-150 g of vermicompost per pot. However, different researchers have got best results at different levels of vermicompost in their respective experimentations. Reddy et al., (1998) registered highest tomato yield with $10 \mathrm{t} \mathrm{ha}^{-1}$ vermicompost application. Similarly, Nagavallemma et al., (2004) documented highest tomato yield following vermicompost incorporation@ @ $\mathrm{t} \mathrm{ha}^{-1}$. In another experiment, vermicompost application @ $2.5 \mathrm{t} \mathrm{ha}^{-1}$ gave highest rice yield of upland rice (Angadi and Radder, 1996).

\section{Benefits of vermicompost}

Vermicompost is a good quality manure that contain several essential nutrients needed by the crops such as nitrogen, phosphorus, potassium, calcium, magnesium and micronutrients viz. iron, zinc, copper, manganese in sufficient quantity that increase the productivity and quality of crops.

Application of vermicompost in soil improves physical, chemical and biological properties of the soil. It improves soil structure due to which soil become porous and permeable to soil and water.

Vermicompost contain sufficient amount of vitamins, amino acids, antibiotics, enzymes and hormones that are helpful in growth and development of plants.

Vermicompost provide complete nutrition to plants and create resistance in plants against insect-pest and diseases.

Vermicompost increase water holding capacity of the soil and save irrigation. Further, it also reduces the expenditure on costly chemical fertilizer inputs thus, reducing overall cost of cultivation.

Weeds like Lantana, Ageratum, Parthenium, Eupatorium and many other weeds harmful to crops could be utilised in vermicompost production.

\section{Effects of vermicompost on crop growth and productivity}

Vermicompost is a potential input for sustainable agriculture. The beneficial effects of vermicompost application in soil have been well documented in several studies. Studies have revealed that plant respond to vermicompost application like 'hormonal induced activity' as it contain high level of nutrients, humic acids and humates (Atiyeh $e t$ al., 2000; Edwards and Burrows, 1988). Some researchers have registered enhanced plant growth following vermicompost addition even though plants are already receiving optimal 
nutrition. Vermicompost also has a positive influence on vegetative growth, stimulating shoot growth and root development (Edwards et al., 2004). The other positive influence of vermicompost application include alterations in morphology of crop plants such as increased leaf area and root branching (Lazcano et al., 2009) and stimulated flowering, increase in the number and biomass of flowers (Arancon et al., 2008; Atiyeh et al., 2002) and overall increase in fruit yield (Arancon et al., 2004a, 2004b; Atiyeh et al., 2000; Singh et al., 2008).

Vermicompost application consistently improved seed germination, enhanced seedling growth and increased plant productivity significantly. Application of vermicompost gave higher germination (93\%), growth and yield of mungbean (Vigna radiate L.) in comparison with no addition of vermicompost (84\%) (Nagavallemma et al., 2004). Similarly, Gutierrez-Miceli et al., (2007) has registered, earlier and better germination in vermicompost imbedded treatments than treatments not involving vermicompost. Vermicompost application $10 \mathrm{t}$ $\mathrm{ha}^{-1}$ along with recommended $\mathrm{N}, \mathrm{P}$ and $\mathrm{K}$ nutrient doses gave maximum pea yield in comparison with sole application of $\mathrm{N}, \mathrm{P}$ and K chemical fertilizers (Reddy et al., 1998).

Similar findings have also been registered by Nagavallemma et al., (2004) while working on tomato. They highlighted that vermicompost incorporation $\left(5 \mathrm{t} \mathrm{ha}^{-1}\right)$ in soil along with recommended $\mathrm{N}, \mathrm{P}$ and $\mathrm{K}$ fertilizer application resulted in highest tomato yield than NPK sole application. While other workers have reported that vermicompost contain certain growth promoting hormone such as auxins, cytokinins and gibberellins, which are secreted by earthworms (Suhane, 2007; Tomati et al., 1987, 1995). Thus, addition of hormones rich vermicompost into the soil resulted in better growth and overall development of plants.
Nagavallemma (2004) has registered significantly higher plemule length of maize seedlings following vermicompost application, indicating the presence of plant growth promoting hormones in vermicompost. Stimulated seed germination in green gram, tomato and petunia after imbedding vermicompost in soil has also been documented by Karmegam et al., (1999); Atiyeh et al., (2000); Zaller (2007), respectively.

Integration of vermicompost with inorganic fertilizers tended to increase the yield of crops such as tomato, potato, rapeseed, groundnut, blackgram, paddy, mulberry and marigold (Kale et al., 1992; Tomati and Galli, 1995; Edwards and Bohlen, 1996; Ghosh et al., 1999; Parthasarathi and Ranganathan, 2002; Ranganathan, 2006; Zaller, 2007; Rajesh Banu et al., 2008). Studies have shown good evidence of plant growth promotion following vermicompost inclusion in crop production (Fosgate and Babb, 1972; Reddy, 1988; Rajkhowa et al., 2000; Atiyeh et al., 2000; Subler et al., 1998). Vermicompost promote root initiation, increase root biomass, enhance plant growth and alters overall plant morphology (Grapelli et al., 1985). Positive results of vermicompost addition to soil in tomato crop have also been registered by Federico et al., (2007).

Vegetative growth of paddy like shoot weight, root weight, root and shoot length influenced significantly by the addition of vermicompost in comparison with sole application of chemical fertilizers (Kale and Bano, 1986). Reddy (1988) also registered increased growth after incorporation of vermicompost in paddy field, thereby supporting the findings of above workers. Similarly, significantly higher yield of lady finger, chillies, water melon and paddy following vermicompost incorporation in soil as compared to farmyard manure application has also been documented by Ismail (1993). 
Imbedding vermicompost in soil along with recommended NPK nutrients doses enhanced paddy yield to the tune of $30 \%$ than sole application of chemical fertilizers (Venkataratnam, 1994). Actually, addition of vermicompost in soil before sowing has immediate benefits as it contain nutrients in plant available form and these nutrients can be directly absorbed by the crop plants.

Vermicompost application $2.5 \mathrm{t} \mathrm{ha}^{-1}$ increased gram and straw yield of rice significantly and saved up to $50 \%$ of recommended NPK fertilizer rates in upland rice (Angadi and Radder, 1996). Earthworms' cast (vermicompost) found to be a better source for enhanced plant growth, dry matter production, productivity and also indicated the possibility of substituting $50 \mathrm{~kg} \mathrm{~N} \mathrm{ha}{ }^{-1}$ from the

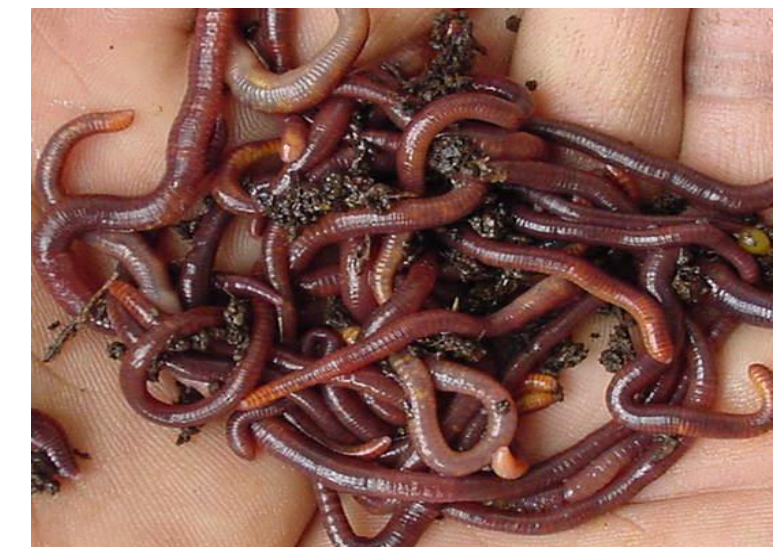

Eisenia fetida recommended dose of $\mathrm{N}$ (Jadhav et al., 1997)). Thus, vermicompost usage reduced dependence on costly fertilizer input and enhanced net returns from rice produce (Nagaranjan, 1997). Several studies have witnessed increased biomass and grain yield in different crops following judicious application of vermicompost and chemical fertilizers (Sarwar, 2007; Sarwar, 2008). Positive changes in the quality of wheat flour because of increased gluten content were reported by Gopinath et al., (2008) in vermicompost imbedded treatments. Beside above presented results, there are several examples in the literature that documented enhanced growth of a wide range of plant species following vermicompost incorporation as it is an instant source of nutrients supply (Edwards, 2004; Grigatti et al., 2007).

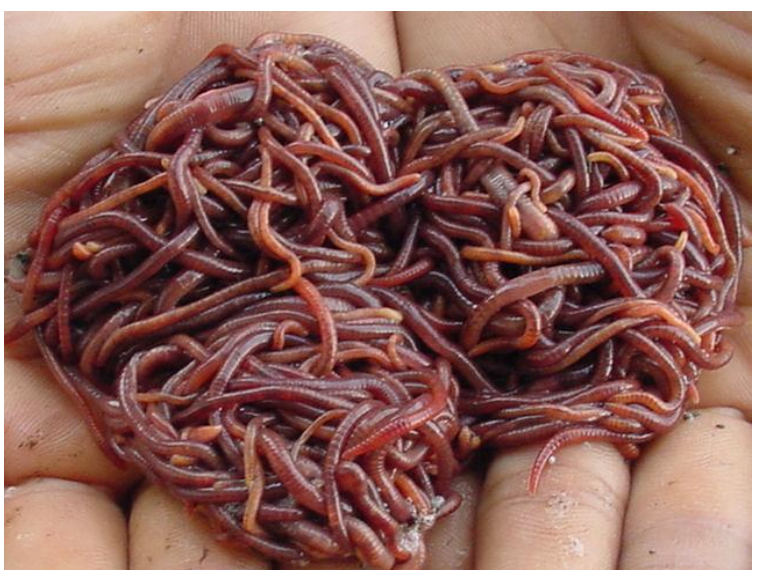

Eudrilus eugeniae
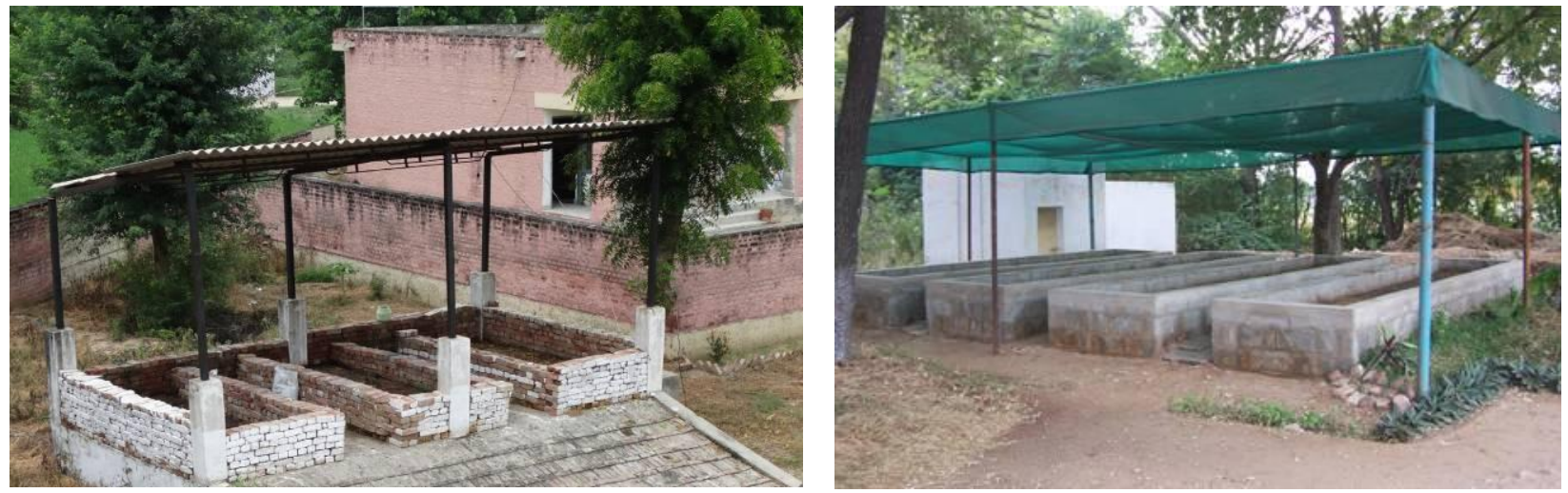

Vermicompost unit 


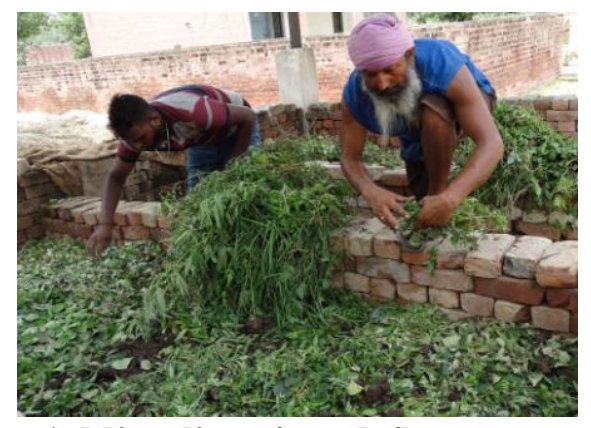

Adding litter/weeds/leaves to vermicompost bed

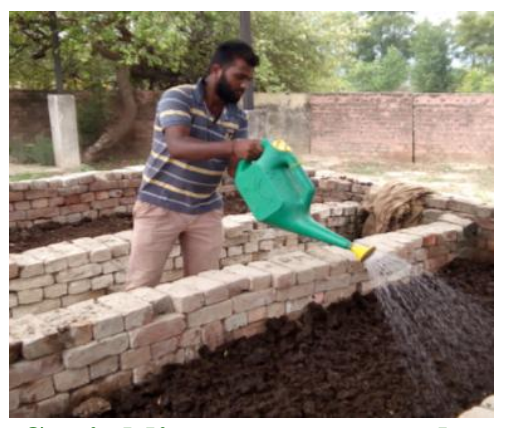

Sprinkling water over the bed

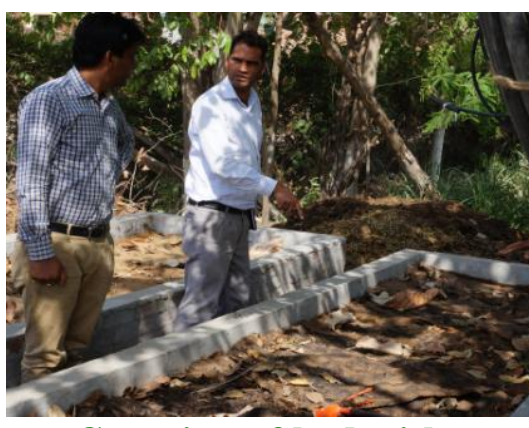

Covering of bed with Gunny bags

Table.1 Nutrient concentration in the vermicompost

\begin{tabular}{|l|}
\hline Nutrient \\
\hline Organic carbon \\
\hline Total nitrogen \\
\hline Total phosphorus \\
\hline Total potassium \\
\hline $\mathrm{Ca}$ and $\mathrm{Mg}$ \\
\hline Available S \\
\hline Copper \\
\hline Iron \\
\hline Zinc \\
\hline
\end{tabular}

\section{Content}

9.15- $17.98 \%$

$1.5-2.10 \%$

$1.0-1.50 \%$

$0.60 \%$

$22.67-47.60 \mathrm{meq} / 100 \mathrm{~g}$

$128-548 \mathrm{ppm}$

$2-9.5 \mathrm{ppm}$

$2-9.30 \mathrm{ppm}$

$5.70-11.5 \mathrm{ppm}$

Source: Online: http://agritech.tnau.ac.in/org_farm/orgfarm_vermicompost.html; http://www.hillagric.ac.in/edu/ coa/agronomy/lect/agron-3610/Lecture-10-BINM-Vermicompost.pdf

Table.2 Comparison between nutritive value of vermicompost and farmyard manure

\begin{tabular}{|c|c|c|}
\hline Element & Vermicompost & Farmyard manure \\
\hline C:N Ratio & 15.5 & 31.3 \\
\hline $\mathrm{N}(\%)$ & 1.6 & 0.5 \\
\hline $\mathrm{P}(\%)$ & 0.7 & 0.2 \\
\hline $\mathrm{K}(\%)$ & 0.8 & 0.5 \\
\hline $\mathrm{Ca}(\%)$ & 0.5 & 0.9 \\
\hline $\mathrm{Mg} \mathrm{( \% )}$ & 0.2 & 0.2 \\
\hline $\mathrm{Fe}\left(\mathrm{mg} \mathrm{kg}^{-1}\right)$ & 175 & 146.5 \\
\hline $\mathrm{Cu}\left(\mathrm{mg} \mathrm{kg}^{-1}\right)$ & 5.0 & 2.8 \\
\hline $\mathrm{Zn}\left(\mathrm{mg} \mathrm{kg}^{-1}\right)$ & 24.5 & 14.5 \\
\hline $\mathrm{Mn}\left(\mathrm{mg} \mathrm{kg}^{-1}\right)$ & 96.5 & 69.0 \\
\hline
\end{tabular}

Source: Punjab State Council for Science and Technology (2010). Online: http://agri.and.nic.in/vermi_culture.htm 


\section{Effects of vermicompost on soil properties}

The presence of earthworms in soil regenerate compacted soils and improves water penetration in such soils. The behavioural activity of earthworms that is feeding, burrowing and casting, modify the physical, chemical and biological properties of organic matter and soil. As discussed earlier, nutrient profile in vermicompost is generally higher than traditional compost. In fact, vermicompost can enhance soil fertility physically, chemically and biologically (Lim et al., 2015). Physically, vermicompost supplemented soils have better aeration, porosity, lower bulk density and higher water retention capacity.

Soil chemical properties such as $\mathrm{pH}$, electrical conductivity, organic matter and nutrient status improved significantly and led to better plant growth and yield owing to vermicompost application (Lim et al., 2015). Moreover, earthworms secrete several hormones, enzymes and vitamins during casting that promote the activity of other beneficial microbes in the soil, thereby improving soil health.

Earthworms' casting contains a high percentage of humus. Humus helps in aggregation of soil particles resulting into better porosity, which in turn improve aeration and water holding capacity of the soils. Moreover, humic acid present in humus provides binding sites for the several plant nutrients viz. calcium, iron, potassium, sulphur and phosphorus. These nutrients are stored in the humic acid in the form readily available nutrients and are released when the plants require them (Adhikary 2012). Earthworm casts ingested soil might create even more favourable environment to plant growth because of higher moisture content and nutrient availability in fresh casts (Hendriksen, 1997).
Jeyabal and Kuppuswamy (2001) have reported increased growth of rice stalks and improvement in soil fertility status following vermicompost application. Earthworm casts are usually considered to be responsible for good soil structure and improve soil physical properties i.e. infiltration, water retention and resistance to erosion (Rose and Wood, 1980). Thus, soils amended with vermicompost have ability to improve soil structure and retain higher moisture content. As discussed earlier, earthworm casts are chemically and biologically rich, hence, soils imbedded with vermicompost show higher cation exchange capacity and have a higher rate of plant growth hormones and humic acids, higher microbial population and activity, and less root pathogens or soil borne diseases (Atiyeh et al., 2002; Arancon et al., 2003a; Postma et al., 2003; Perner et al., 2006) and overall improvement in plant growth and yield (Arancon et al., 2003b, 2004a). Lee (1992) reported that microorganisms in the worm casts might fix atmospheric $\mathrm{N}$ in such quantities that are significant for the earthworm metabolism and as a source of nitrogen for plant growth.

Uee (1985) registered 80\% increase in hydraulic conductivity and six fold increase in water infiltration following vermicompost addition in soil. The findings of Casenave and Valentin (1988) supported above results as they have also been reported five folds higher infiltration rate in soil following vermicompost application. Martin (1991) reported that earthworm casts had increased the proportion of macro-aggregates significantly from 25.4 to $31.2 \%$.

\section{Effects of vermicompost on soil organic matter}

Earthworm casts ingested soils often have much higher content of soil organic carbon and nutrients availability as compared to 
surrounding soils (Lee, 1985). The studies undertaken by Maheswarappa, (1999) revealed that vermicompost addition in soil enhanced organic carbon status, decreased bulk density, improved soil porosities and water holding capacities, increased microbial populations and dehydrogenase activity in the soils.

It has been documented that organic matter content in worm casts was about four times more than in surface soil with average values of 48.2 and $11.9 \mathrm{~g} \mathrm{~kg}^{-1}$ soil, respectively (Khang, 1994).

Moreover, earthworms contribution to $\mathrm{N}$ turnover in cultivated soils ranged from 3 to $60 \mathrm{~kg} \mathrm{ha}^{-1}$ year $^{-1}$ (Crossley, 1988; Bostom, 1988), thereby enhancing $\mathrm{N}$ availability to plants (Tiwari et al., 1989; Hullugalle and Ezumah, 1991).

\section{Precautions during vermicompost production}

Select a shady spot for vermicompost making or provide a shed/roof over the unit so that earthworm may be avoided from the direct contact of sun rays and rains.

Maintain optimum moisture and temperature conditions in the vermicompost bed/unit by sprinkling water regularly over the gunny bags.

Avoid spraying of any kind of insecticides and fungicides over the vermicompost bed.

The height of vermicompost bedding material should not exceed $3-3.5$ feet as it may increase the temperature inside the bed and also create aeration problem inside and led to death of earthworm.

To escape the earthworm from hen, birds, etc. cover the vermicompost bed with sieve.

\section{Epilogue}

Overall, nutrient profile in vermicompost is generally higher than traditional compost. Vermicompost application in soil not only improves structure and aggregation but, also enhance organic matter level, nutrient status, cation exchange capacity, microbial activities, microbial biomass carbon and enzymetic activities. Thereby, help in promoting plant growth and sustain soil health. Hence, this input is proven as boon to the farmers. To take full advantage of vermicompost, plough it well in the soil at the time of sowing. The expenditure on costly chemical fertilizer input may be reduced to some extent by applying vermicompost in crops.

\section{Acknowledgement}

The authors are highly thankful to researchers whose findings are included directly or indirectly in preparing this manuscript.

\section{References}

Adhikary, S. 2012. Vermicompost, the story of organic gold: A review. Agricultural Sciences, 3(7): 905-917.

Alves, W.L., and Passoni, A.A. 1997. Compost and vermicompost of urban solid waste in Licania tomentosa (Benth) seedlings production to arborization. Pesqui. Agropecu Bras, 32 (10): 1053-1058.

Angadi, V.V., and Radder, G.D. 1996. In: Organic Farming and Sustainable Agriculture. National Seminar, G.B.P.U.A.T, Pantnagar. pp. 34.

Arancon, N., S. Lee, C. Edwards, and Atiyeh, R. 2003a. Effects of humic acids derived from cattle, food and paper-waste vermicomposts on the growth of greenhouse plants. Pedobiologia, 47 (5): 741-744.

Arancon, N.Q., C.A. Edwards, A. Babenko, J. Cannon, P. Galvis, and Metzger, J.D. 2008. Influences of vermicomposts, 
produced by earthworms and microorganisms from cattle manure, food waste and paper waste, on the germination, growth and flowering of petunias in the greenhouse. Applied Soil Ecology, 39: 91-99.

Arancon, N.Q., C.A. Edwards, and Atiyeh, R. 2004. Effects of vermicomposts produced from food waste on the growth and yields of greenhouse peppers. Bioresour. Technol 93: 139-144.

Arancon, N.Q., C.A. Edwards, P. Bierman, C. Welch, and Metzger, J.D. 2004. The influence of vermicompost applications to strawberries: Part I. Effects on growth and yield. Biores. Technol., 93: 145-153.

Arancon, N.Q., S. Lee, C.A. Edwards, and Atiyeh, R.M. 2003b. Effects of humic acids and aqueous extracts derived from cattle, food and paper-waste vermicomposts on growth of greenhouse plants. Pedobiologia, 47: 744-781.

Atiyeh, R., S. Lee, C. Edwards, Q. Arancon, and Metzger, J. 2002. The influence of humic acids derived from earthworm processed organic wastes on plant growth. Bioresour. Technol, 84 (1): 7-14.

Atiyeh, R.M., N. Arancon, C.A. Edwards, and Metzger, J.D. 2002. The influence of earthworm-processed pig manure on the growth and productivity of marigolds. Bioresour. Technol 81: 103-108.

Atiyeh, R.M., N.Q. Arancon, C.A. Edwards, and Metzger, J.D. 2000. Influence of earthworm-processed pig manure on the growth and yield of greenhouse tomatoes. Bioresour. Technol, 75: 175-180.

Atiyeh, R.M., S. Subler, C.A. Edwards, and Metzger, J. 1999. Growth of tomato plants in horticultural potting media amended with vermicompost. Pedobiologia, 43: 724-728.

Atiyeh, R.M., S. Subler, C.A. Edwards, G. Bachman, J.D. Metzger, and Shuster, W. 2000. Effects of Vermi-composts and Composts on Plant Growth in Horticultural Container Media and Soil. Pedobiologia, 44: 579-590.
Bansal, S., and Kapoor, K.K. 2000. Vermicomposting of crop residues and cattle dung with Eisenia foetida. Bioresour. Technol 73 (2): 9598.

Boral, E., C. Sachin, and Aranda, E. 1997. Earthworm activity affects soil aggregation. Soil Biology and Biochemistry, 29 (3): 431-439.

Bostom. 1988. Pedobiologia, 3: 379-388.

Chowdeppa, P., C.C. Biddappa, and Sujatha, S. 1999. Effective recycling of organic waste in arecanut (Areca ctechu L.) and cocoa (Theombrome cacoa L.) plantation through vermicomposting. Indian J Agric Sci., 69: 563-566.

Cook, S.M.F., and Linden, D.R. 1996. Effect of food type and placement on earthworm (Aporrectodea tuberculata) burrowing and soil turnover. Biology and fertility of soil, 21 (3): 201206.

Crossley. 1988. Applied Eco, 26: 505-520.

Curry, J.P. 1987. The invertebrate fauna of grassland and its influence on productivity. The composition of the fauna. Grass For. Sci., 42: 103-120.

Dominguez, J., and Edwards, C.A. 2004. Vermicomposting organic wastes: A review. In: Soil Zoology for Sustainable Development in the 21st Century (Shakir, S.H., Mikhail, W.Z.A., Eds).

Edwards, C.A. 1998. The use of earthworm in the breakdown and management of organic waste. In: Earthworm Ecology. ACA Press LLC, Boca Raton, FL, pp. 327-354.

Edwards, C.A., and Bohlen, P.J. 1996. Biology and Ecology of Earthworms. Chapman and Hall, London. pp. 426.

Edwards, C.A., and Burrows, I. 1988. The potential of earthworms composts as plant growth media. In: Earthworms in Waste and Environmental Management (Edward, C.A., Neuhauser, E.F., Eds.), SPB Academic Publishing, The Hague, The Netherlands, 21-32.

Edwards, C.A., J. Domínguez, and Arancon, N.Q. 2004. The influence of vermicomposts on plant growth and pest incidence. In: Soil Zoology for 
Sustainable Development in the 21st Century (Shakir, S.H., Mikhaïl, W.Z.A., Eds.), Cairo, pp. 397-420.

Federico, J.S., J.A. Borraz, M. Molina, C. Nafate, C. Archila, and Oliva, L.M. 2007. Vermicompost as a soil supplement to improve growth, yield and fruit quality of tomato (Lycopersicum esculentum). Bioresour Tech, 98 (15): 2781-2786.

Fosgate, O.T., and Babb, M.R. 1972. Biodegradation of animals waste by Lumbricus terrestris, earthworms. Journal of Diary Science, 55 (6): 870-872.

Ghosh, M., G.N. Chattopadhyay, and Baral. 1999. Transformation of phosphorus during vermicomposting. Bioresour. Technol, 69: 149-154.

Gopinath, K.A., S. Saha, B.L. Mina, H. Pande, S. Kundu, and Gupta, H.S. 2008. Influence of organic amendments on growth, yield and quality of wheat and on soil properties during transition to organic production. Nutr. Cycl. Agroecosys., 82: 51-60.

Grapelli, A., U. Tomati, E. Galli, and Vergari, B. 1985. Earthworm casting in plant propagation. Hort Sc., 20: 874876.

Grigatti, M., M. Giorgonni, and Ciavatta, C. 2007. Compost-based growing media: influence on growth and nutrient use of bedding plants. Bioresour Technol, 98: 3526-3534.

Gutierrez-Miceli, F.A., J. Santiago-Borraz, J.A.M. Molina, C.C. Nafate, M., AbudArchila, M.A.O. Llaven, R. RinconRosales, and Dendooven, L. 2007. Vermicompost as a soil supplement to improve growth, yield and fruit quality of tomato (Lycopersicum esculentum). Bioresour. Technol., 98 (15): 2781-2786.

Hendriksen. 1997. Biotech. Bioeng, 23: 18121997.

Hullugalle, N.R., and Ezumah, H.C. 1991. Agric., Ecosystems and Environ, 35: 5563.

Ismail, S.A. 1993. Composting. through earthworms. In: Monograph series on the engineering of photosynthetic systems.
Shri. AMM. Murugappa Chettiar Research Centre Taramani. Madras.

Jadhav, A.D. 1997. J. Maharashtra agric. Univ., 22: 249-250.

Jeyabal, G., and Kuppuswamy. 2001. Recycling of organic wastes for the production of vermicompost and its response in ricelegume cropping system and soil fertility, Eur. J. Agron, 15 (3): 153170.

Kale, R.D., and Bano, K. 1986. In: Proceedings Nat. Semi on Organic waste Utilization. pp. 151-160.

Kale, R.D., B.C. Mallesh, B. Kubra, and Bagyaraj, D.J. 1992. Influence of vermicompost application on the available macronutrients and selected microbial populations in a paddy field. Soil Biol. Biochem, 24: 1317-1320.

Karmegam, N., K. Alagermalai, and Daniel, T. 1999. Effect of vermicompost on the growth and yield of greengram (Phaseolus aureus Rob.). Tropical Agriculture, 76 (2): 143-146.

Khang, B.T. 1994. Soil Fert. Soils, 18: 193-199.

Kiehl, J.C. 2001. Producao de composto organico $\mathrm{e}$ vermicomposto. Informe Agropecua rio, Belo Horizonte, 22 (212): 40-52.

Lazcano, C., J. Arnold, A. Tato, J.G. Zaller, and Domín- guez, J. 2009. Compost and vermicompost as nursery pot components: Effects on tomato plant growth and morphology. Spanish Journal of Agricultural Research, 7: 944-951.

Lee, K.E. 1985. Earthworms, their Ecology and Relationships with Land Use. Academic Press, Sydney, pp. 411.

Lee, K.E. 1992. Soil Bio Biochem, 24: 17651771.

Lim, S.L., T.Y. Wu, P.N. Lim, and Shak, K.P. 2015. The use of vermicompost in organic farming: overview, effects on soil and economics. Journal of Science and Food Agriculture, 95 (6): 1143-1156.

Mahewarappa, H.P., H.V. Nanjappa, and Hegde, M.R. 1999. Influence of organic manures on yield of arrowroot, soil physico-chemical and biological properties when grown as intercrop in 
coconut garden. Annals of Agricultural Research, 20: 318-323.

Martin, A. 1991. Biology and Fertility of Soils, 11: 234-238.

Nagarajan, S. 1997. Kisan World, 24(8): 49-50. Nagavallemma, K.P., S.P. Wani, L. Stephane, V.V. Padmaja, C. Vineela, M. Babu,-Rao, and Sahrawat, K.L. 2004. Vermicomposting: Recycling wastes into valuable organic fertilizer. In: Global Theme on Agrecosystems Report no. 8. International Crops Research Institute for the Semi-Arid Tropics, Patancheru, India, pp. 20.

Orozco, F.H., J. Cegarra, L.M. Trujillo, and Roig, A. 1996. Vermicomposting of coffee pulp using the earthworm Eisenia fetida: effects on $\mathrm{C}$ and $\mathrm{N}$ contents and the availability of nutrients. Biol. Fert. Soils, 22: 162-166.

Parthasarathi, K., and Ranganathan, L.S. 2002. Supplementation of pressmud vermicasts with NPK enhances growth and yield in leguminous crops (Vigno mungo and Arachis hypogaea). J. Curr. Sci., 2: 3541.

Perner, H., D. Schwarz, and George, E. 2006. Effect of mycorrhizal inoculation and compost supply on growth and nutrient uptake of young leek plants growth on peat-based substrates. Horti. Sci., 41, 628632.

Pimentel, D. 1996. Green Revolution and chemical hazards. Sci Total Environ, 188: 86-98.

Postma, J., M. Montanari, Van den, and Boogert, P.H.J.F. 2003. Microbial enrichment to enhance disease suppressive activity of compost. Eur. J. Soil Biol., 39: 157-163.

Rajesh-Banu, J., I.T. Yeom, S. Esakkiraj, N. Kumar, and Logakanthi, S. 2008. Biomanagement of sago-sludge using an earthworm Eudrilus eugeniae. J. Environ. Biol., 29: 143-146.

Rajkhowa, D.J., A.K. Gogoi, R. Kandali, and Rajkhowa, K.M. 2000. Effect of vermicompost on greengram nutrition. $J$. Ind. Soc. Soil Sci., 48: 207-208.
Ranganathan, L.S. 2006. Vermibiotechnology from Soil Health to Human Health. Agrobios., India.

Reddy, M.V. 1988. The effect of casts of Pheretima alexandri (Beddard) on the growth of Vinca rosea, and Oryza sativa L. In: Edwards, C.A., Neuhauser, E. (eds), Earthworms in Waste and Environmental Management. SPB Academic Press, The Hague, The Netherlands, pp. 241-248.

Reddy, R., M. Reddy, Y.T.N. Reddy, N.S. Reddy, N. Anjanappa, and Reddy, R. 1998. Effect of organic and inorganic sources of NPK on growth and yield of pea (Pisum sativum L.). Legume Res., 21(1): 57-60.

Rose, C.J., and Wood, A.W. 1980. Some environmental factors affecting earthworm populations and sweet potato production in Tari basin, Papua New Guniea Highlands. Papua New Guinea Agric. J., 31: 1-13.

Rostami, R., A. Nabaei, and Eslami, A. 2009. Survey of optimal temperature and moisture for worms' growth and operating vermicompost production of food wastes. Health and environment, 1 (2): 105-112.

Sarwar, G., N. Hussain, H. Schmeisky, and Muhammad, S. 2007. Use of compost an environment friendly technology for enhancing rice-wheat production in Pakistan. Pak J Bot, 39 (5): 1553-1558.

Sarwar, G., N. Hussain, H. Schmeisky, S. Muhammad, M. Ibrahim, and Safdar, E. 2008. Improvement of soil physical and chemical properties with compost application in rice-wheat cropping system. Pak J Bot, 40: 275-282.

Shi-wei, Z., and Fu-Zhen, H. 1991.The nitrogen uptake efficiency from $15 \mathrm{~N}$ labeled chemical fertilizer in the presence of earthworm manure (cast). In: Advances in Management and Conservation of Soil Fauna (Veeresh G.K. et al., Eds.) Oxford and IBH publishing Co., Bombay. pp. 539- 542. 
Singh, R., R.R. Sharma, S. Kumar, R.K. Gupta, and Patil, R.. 2008. Vermicompost substitution influences growth, physiological disorders, fruit yield and quality of strawberry (Fragaria xananassa Duch.). Bioresour. Technol 99: 8507-8511.

Subler, S., C, A. Edwards, and Metzger, J.D. 1998. Comparing vermicomposts and composts. Biocycle, 39: 63-66.

Suhane, R.K. 2007. Vermicompost. Rajendra Agriculture University, Pusa, pp. 88.

Tiwari, K.N. 1989. Fertilizer management in cropping system for increased efficiency. Fertilizer News, 25(3): 3-20.

Tomati, U., A. Grappelli, and Galli, E. 1987. The presence of growth regulators in earthworm worked wastes. In: Proceeding of International Symposium on 'Earthworms' (Bonvicini-Paglioi, A.M., Omodeo, P., Eds.), Bologna-Carpi, March 31 - April 4, 1985. pp. 423-436.

Tomati, U., and Galli E. 1995. Earthworms, soil fertility and plant productivity. Acta Zool Fenn, 196: 11-14.
Tomati, U., and Galli, E. 1995. Earthworms, soil fertility and plant productivity. Acta Zoologica Fennica, 196: 11-14.

Tomati, V., A. Grappelli, and Galli, E. 1995. The Hormone like Effect of Earthworm Casts on Plant Growth. Biology and Fertility of Soils, 5: 288-294.

Ushakumari, K., P. Prabhakumari, and Padmaja, P. 1999. Efficiency of vermicomposts on growth and yield of summer crop okra (Abelmoschus esculentus Moench). J. Trop. Agric., 37: 87-88.

Vasanthi, D., and Kumarasamy, K. 1999. Efficacy of vermicompost to improve soil fertility and rice yield. Journal Indian Society of Soil Sciences, 42 (2): 268-272.

Venkataratnam, L. 1994. Food Security in Hormony with Nature. 3'd IFOAM-ASIA Scientific Conference and General Assembly. pp. 59.

Zaller, J.G. 2007. Vermicompost as a substitute for peat in potting media: Effects on germination, biomass allocation, yields and fruit quality of three tomato varieties. Scientia Horticulturae, 112: 191-199.

\section{How to cite this article:}

Anil Kumar, C.H. Bhanu Prakash, Navjot Singh Brar and Balwinder Kumar. 2018. Potential of Vermicompost for Sustainable Crop Production and Soil Health Improvement in Different Cropping Systems. Int.J.Curr.Microbiol.App.Sci. 7(10): 1042-1055.

doi: https://doi.org/10.20546/ijcmas.2018.710.116 